\title{
Genetic biomarkers in chronic venous disease
}

\author{
Raffaele Serra*,1,2, Lwanga Ssempijja ${ }^{1,2}$, Michele Provenzano ${ }^{3}$ \& Michele Andreucci ${ }^{3}$ \\ ${ }^{1}$ Interuniversity Center of Phlebolymphology (CIFL), International Research and Educational Program in Clinical and Experimental \\ Biotechnology at the Department of Medical and Surgical Sciences, University Magna Graecia of Catanzaro, Viale Europa 88100 \\ Catanzaro, Calabria, Italy \\ ${ }^{2}$ Department of Medical \& Surgical Sciences, University Magna Graecia of Catanzaro, Viale Europa 88100 Catanzaro, Calabria, Italy \\ ${ }^{3}$ Department of Health Sciences, University Magna Graecia of Catanzaro, Viale Europa 88100 Catanzaro, Calabria, Italy \\ *Author for correspondence: Tel.: +39 0961364 7380; rserra@unicz.it
}

\section{“HFE gene polymorphisms seem to play a role in susceptibility to varicose vein development as well as in disease progression and ulcer formation"}

First draft submitted: 17 September 2019; Accepted for publication: 1 November 2019; Published online: 13 February 2020

Keywords: chronic venous disease $\bullet$ genetic $\bullet$ varicose vein $\bullet$ venous insufficiency

Chronic venous disease (CVD) is a very common clinical syndrome affecting up to $80 \%$ of the western world. CVD involves primarily peripheral vein circulation of lower limbs with the onset of venous reflux. In healthy subjects, in the erect position, the blood column in the lower limbs shows a venous pressure of $90-100 \mathrm{mmHg}$ at the ankle, and the lower limbs veins are endowed with means to deal with this hydrostatic pressure in order to avoid blood pooling in the legs. Therefore, bicuspid valves are located along the superficial and profound veins, to enable a unidirectional blood flow toward the heart and prevent blood return down to the lower limb segments. In particular, the valves work in harmony with venous muscle pumps, mainly in the calf as well in the foot and thigh, to permit blood return to the heart against gravity. Venous reflux is seen when valves damage or impairment occurs determining venous hemodynamic dysfunction. Valvular reflux leads to an elevation in ambulatory venous pressure and a number of clinical pathologic events such as varicose veins, lower limbs edema, pain, itching, skin changes and venous ulceration (VU). Varicose veins are the main clinical manifestation of CVD happening in a quarter to a third of the Western adult population [1-15]. Several studies have proposed a familiar transmission in the cause of varicose veins that can be due also to genetic factors [14,16-21].

\section{Main genetic factors related to vascular development \& angiogenesis} Forkhead box protein C2 (FOXC2) gene

The FOXC2 gene encodes a regulatory transcription factor, which plays a role in normal development of the lymphatic and venous system, in particular the development and the maintenance of venous and lymphatic valves function. FOXC2 is a Forkhead transcriptional factor coding for the gene found on chromosome 16q24.1. FOXC2 is needed for interactions between mesenchymal cells during the formation of lymphatic and blood vessels, lymph node and valve formation [22-27].

FOXC2 regulates expression of several genes encoding angiogenesis control proteins, such as delta-like 4, Hey2, integrin beta 3, CXCR4, Ang2 and so on [28-30].

Several studies found FOXC2 and/or related polymorphisms near the FOXC2 gene associated with varicose veins [31-33].

\section{Vascular endothelial growth factor A gene}

Vascular endothelial growth factor A (VEGF-A) is a physiological and pathological angiogenesis regulator that plays a pivotal role vascular reactivity and integrity maintenance. It binds to receptors of VEGFR2 or VEGFR1 and it is a selective endothelial cell mitogen that promotes endothelial cell proliferation, migration and differentiation. VEGF2 is the main signaling receptor of VEGF-A moderating nearly all its biological actions in the endothelial cells, whereas VEGFR1 is only a decoy receptor [34,35]. VEGF-A increases the expression and production of endothelial nitric oxide synthase [36-38] and also promotes inflammation by stimulating expression of adhesion 
molecule-1 (ICAM-1), vascular cell adhesion molecule (VCAM-1) and E-selectin on endothelial cells [39]. Another study demonstrated that changes in mRNA expression, as well as in the contents of VEGF-A, VEGF R1 and VEGF R2, in the wall of varicose veins may explain the clinical symptoms of the disease and may predispose to its progression [40].

\section{Main genetic factor related to vein wall integrity}

Matrix metalloproteinases (MMPs) and tissue inhibitor of metalloproteinases (TIMPs) greatly impact vascular remodeling and may play a pivotal role in CVD and, in particular, in varicose vein formations for their impact on vein wall integrity [41].

Existing studies show that MMP-2 has a major role in regulating extracellular matrix (ECM) components of the venous wall [42]. In fact, the increase in MMP-2 induces relaxation of the veins, leading to venous dilation, varicose vein and chronic venous insufficiency (CVI) that is the most severe form of CVD [43,44]. The induction of MMP expression is mediated by transcription factor activator protein-1 (AP-1), where the latter is activated by strain in the venous wall due to increased hydrostatic pressure [45]. TIMPs control the activation of proenzymes and substrate degradation [46]. MMPs expression and its activity have been studied in various patients with varicose veins, as well as in control subjects [47]. In a Chinese study, it was suggested that polymorphisms in the promoter region of MMP-9 and TIMP-2 are associated with varicose veins [41]. Also, the C allele -418G for TIMP2 seems to be significantly associated with risk of varicose veins [48].

Therefore, any changes in the mechanism or expression of TIMPs and MMPs can lead to changes in venous structure, favoring the development of varicose veins and other symptoms in CVD [47].

\section{Hemochromatosis genes \& varicose veins}

Some researchers studied the influence of hemochromatosis genes on development of varicose veins. Several metabolic processes require iron to function, iron is bound to transferrin in plasma as well is free circulating iron nontransferrin-bound iron, which can be toxic as it has a capability of generating reactive oxygen species [49]. Reactive oxygen species are one of the major factors that facilitate vascular injury in cardiovascular diseases [50-52]. There is an elevated concentration of iron in serum of subjects with CVI compared with the one of healthy individuals [53-55]. Non-transferrin-bound iron promotes the expression of endothelial adhesion molecules, prompting endothelium to smooth muscle cell signaling that incites phenotype change and induct remodeling of venous walls. HFE gene polymorphisms seem to play a role in susceptibility to varicose vein development as well as in disease progression and ulcer formation [56].

\section{Methylenetetrahydrofolate reductase mutations in varicose veins}

A recent study examined the mutations of polymorphisms of methylenetetrahydrofolate reductase mutations (MTHFR) relationship with varicose veins development. There are two studied polymorphisms mutations; c.677C $>\mathrm{T}$ where there is an alanine to valine substitution (p.Ala222Val) in a catalytic domain of MTHFR protein, while c.1298A > C polymorphism leads to a substitution of glutamine to alanine at the codon position 429 [57], reduced activity of these polymorphisms is said to lead to a reduction in DNA methylation [58]. A reduction in DNA methylation leads to an anomalous expression of matrix and structural proteins, as well as reduced DNA integrity leading to premature aging of venous tissue, which is an advantageous makeup for development of varicose veins [59]. One study denoted that there was a relationship between a polymorphism c.677C $>\mathrm{T}$ missense mutation with the risk of developing varicose veins [60]. In another study, both polymorphism c.677C $>$ T homozygous or heterozygous phenotype, which is associated with a trunk phenotype, and heterozygous or homozygous c.1298A $>\mathrm{C}$, which is associated with perforator phenotype, were linked to the development of varicose veins [58].

\section{Genome-wide association study in varicose veins}

Genome-wide association study (GWAS) is a tool used to examine genes implicated in disease susceptibility. The first of its kind in varicose veins was performed by '23andme' biotechnology company [60]. The research was done from the customer base of '23andme' on European individuals, 12 SNPs associated with varicose veins at a genome wide significance level were discovered signaling for $A B O$ gene. In particular, they found the association between the A blood group and varicose veins, confirming the results of a previous study [61]. 
A recent GWAS showed several loci related to CVD susceptibility (EFEMP1, KCNH8 and SKAP2). The gene EFEMP1 is related fibulin-3, an ECM glycoprotein that is able to alter the expression of MMPs and TIMPs, which may affect ECM components and vessel elasticity [62].

Another recent GWAS identified rs4151657 in the complement factor B gene, located in the major histocompatibility complex (MCHIII) genomic sub-region that seems to effectively affect varicose vein risk. This region is also important for the association with autoimmune diseases and height.

The complement system, related to chronic inflammation, can be also responsible of skin changes in CVI [63].

\section{Future perspective}

Future studies are needed in order to confirm and to better expand on previous findings. Future studies should also focus on wider populations of affected patients and populations of healthy subjects at risk of developing the disease. Considering the high prevalence of the disease, futher GWASs seem to be particularly appropriate in order to investigate on the genetic basis of CVD.

\section{Conclusion}

CVD is widespread in the Western world and its more severe manifestations are particularly present in elderly people suffering from CVI, and it is characterized in its later stage with VU, which also accounts for nearly $70 \%$ of all chronic leg ulcers. VU is associated with a decreased quality of life and with an important economic burden. Treatment is represented by graduated elastic compression stockings or devices, venoactive drugs and several kinds of open surgical and endovascular interventions, and, although they were found useful for symptomatic relief of the disease, none of them appear to effectively change the natural history of the disease [64,65]. Hence, prevention based on risk factors, such as the genetic ones, and, hypothetically, gene therapy may be considered an effective tool of treatment, in order to limit the social economic burden of such an important disease. Several studies conducted in the areas of phlebology and wound care showed the importance of several genetic biomarkers, used in the context of precision medicine, and confirmed the importance of their use in the context of clinical practice, in order to effectively improve clinical care in this area [66,67].

\section{Author contributions}

R Serra participated in the conception and design of the work; the acquisition, analysis and interpretation of data, drafting of the work; and critical revision for important intellectual content. He gave final approval of the version to be published. He also gave the agreement to be accountable for all aspects of the work in ensuring that questions related to the accuracy or integrity of any part of the work are appropriately investigated and resolved. L Ssempijja participated in the design of the work, the acquisition of data and the drafting of the work. He gave final approval of the version to be published. He also agreed to be accountable for all aspects of the work in ensuring that questions related to the accuracy or integrity of any part of the work are appropriately investigated and resolved. M Provenzano participated in acquisition of data and the drafting of the work. He gave final approval of the version to be published. He also agreed to be accountable for all aspects of the work in ensuring that questions related to the accuracy or integrity of any part of the work are appropriately investigated and resolved. M Andreucci participated to the acquisition of data and the drafting of the work. He revised it critically for important intellectual content. He gave final approval of the version to be published. He also agreed to be accountable for all aspects of the work in ensuring that questions related to the accuracy or integrity of any part of the work are appropriately investigated and resolved.

\section{Financial \& competing interests disclosure}

The authors have no relevant affiliations or financial involvement with any organization or entity with a financial interest in or financial conflict with the subject matter or materials discussed in the manuscript. This includes employment, consultancies, honoraria, stock ownership or options, expert testimony, grants or patents received or pending, or royalties.

No writing assistance was utilized in the production of this manuscript.

\section{References}

1. Serra R, Grande R, Butrico L, Fugetto F, de Franciscis S. Epidemiology, diagnosis and treatment of chronic venous disease: a systematic review. Chirurgia 29(2), 34-45 (2016).

2. Caggiati A, Bergan JJ et al. An International interdisciplinary consensus committee on venous anatomical terminology. Nomenclature of the veins of the lower limbs: an international interdisciplinary consensus statement. J. Vasc. Surg. 36(2), 416-422 (2002).

3. Recek C. Conception of the venous hemodynamics of the lower extremity. Angiology 57, 556-563 (2006). 
4. Mòzes G, Carmichael SW, Gloviczki P. Development and anatomy of the venous system. In: Handbook of Venous Disorders (2nd Edition). Gloviczki P, Yao JS (Eds). Edward Arnold Publishers, NY, 11-24 (2001).

5. Padberg F. The physiology and hemodynamics of normal venous circulation. In: Handbook of Venous Disorders (2nd Edition). Gloviczki P, Yao JS (Eds). Edward Arnold Publishers, NY, 25-35 (2001).

6. Porter JM, Moneta GL. International consensus committee on chronic venous disease. Reporting standards in venous disease: an update. J. Vasc. Surg. 21(4), 635-645 (1995).

7. Fowkers FG, Lee AJ, Evans CJ, Allan PL, Bradbury AW, Ruckley CV. Lifestyles risk factors for lower limb venous reflux general population; Edinburg vein study. Int. J. Epidemiol. 30(4), 846-852 (2001).

8. Weddell JM. Varicose veins pilot survey, 1966. Br. J. Prev. Soc. Med. 23(3), 179-186 (1969).

9. Abraham JH, Hopp C, Epstein LM. The epidemiology of varicose veins: a survey in western Jerusalem. J. Epidemiol. Commun. H. 35(3), 213-217 (1981).

10. Novo S, Avellone G, Pinto A. Prevalence of primitive varicose veins of the lower limbs in a randomized population sample in western sicily. Int. Angiol. 7, 176-181 (1988).

11. Sadik NS. Predisposing factors of varicose veins telangiectatic leg veins. J. Dermatol. Surg. Oncol. 18(10), 883-886 (1992).

12. Krijrum RMA, De Boer Em, Bruynzeel DP. Epidemiology of venous disorders in the general and occupational population. Epidemiol. Rev. 19(2), 294-309 (1997).

13. Evans CJ, Allan PL, Lee AS et al. Prevalence of venous reflux the general population on duplex scanning, the Edinburg vein study. $J$. Vasc. Jurg. 28(5), 767-776 (1998).

14. Jacobs BN, Andraska EA, Obi AT, Wakefield TW. Pathophysiology of varicose veins. J. Vasc. Surg. Venous. Lymphat. Disord. 5(3), 460-467 (2017).

15. Serra R, Andreucci M, De Caridi G, Massara M, Mastroroberto P, de Franciscis S. Functional chronic venous disease: a systematic review. Phlebology 32(9), 588-592 (2017).

16. Carpentier PH, Maricq HR, Biroc, Poncot-makinem CO, Franco A. Prevelence, risk factorsand clinical patterns of chronic venous disorders of lower limbs: a population based study in France. J. Vasc. Surg. 40(4), 650-659 (2004).

17. Hirai M, Naiki K, Nakayama R. Prevalence and risk factors of varicose veins in Japanese women. Angiology 41(3), 228-232 (1990).

18. Komjuolu B, Goldeli O, KulanK, Catinarslan B, Kamjuoglu JS. Prevalence and risk factors of varicose veins in an eldery population. Gerontology 40(1), 25-31 (1994).

19. Kroeger K, Ose C, Rudofsky G, Roesener J, Hirche H. Risk factors for varicose veins. Int. Angiol. 23(1), 29-34 (2004).

20. Laurikka JO, Sisto T, Tarkka MR, Auvinem O, Hakama M. Risk indicators for varicose veins in forty to sixty year olds in the Tamere varicose vein study. World J. Surg. 26(6), 648-651 (2002).

21. Frebig A, Krushe P, Wolf A et al. Heritability of chronic venous disease. Hum. Genet. 127(6), 669-674 (2010).

22. Mellor RH, Brice G, Stanton AW,, Lymphoedema Research Consortium. Mutations in FOXC2 are strongly associated with primary valve failure in veins of the lower limb. Circulation 115(14), 1912-1920 (2007).

23. Mangion J, Rahman N, Mansour S et al. A gene for lymphedema - distichiasis maps to 16q24.3. Am. J. Hum. Gen. 65, 427-432 (1999).

24. Petrova TV, Karpanen T, Norrmén C et al. Defective valves and abnormal mural cell recruitment underlie lymphatic vascular failure in lymphedema distichiasis. Nat. Med. 10(9), 974-981 (2004).

25. Kume T. FOXC2 transcription factor: a newly described regulator of angiogenesis. Trends Cardiovasc. Med. 18(6), $224-228$ (2008).

26. Shimoda H, Bernas MJ, Witte MH. Dysmorphogenesis of lymph nodes in FOXC2 in haploinsufficient mice. Histochem. Cell Biol. 135(6), 603-613 (2011).

27. Wu X, Liu N-F. FOXC2 transcription factor: a novel regulator of lymphagiogenesis. Lymphology 44(1), 35-41 (2011).

28. Hayashi H, Kume T. Foxc transcription factors differently regulate DII2 and Hey2 expression by interacting with VEGF-Notch signaling pathways in endothelial cells. PLoS ONE 3(6), e2401 (2008).

29. Hayashi H, Kume T. Foxc2 transcriptional factor as a regulator of angiogenesis via induction of integrin beta3 expression. Cell Adh. Migr. 3(1), 24-26 (2009).

30. Hayashi H, Kume T. Foxc transcriptional factors regulate expression of the chemokine receptor CXCR4 in endothelial cells and CXCL12-induced cell migration. Biochem. Biophys. Res. Commun. 367(3), 584-589 (2008).

31. Serra R, Buffone G, de Franciscis A et al. A genetic study of chronic venous insufficiency. Ann. Vasc. Surg. 26(5), 636-642 (2012).

32. Surendran S, Ramegowda KS, Sureesh A et al. Arterialization and anomalous vein wall remodeling in varicose veins is associated with upregulated FoxC2 DII4 pathway. Lab. Invest. 96(4), 399-408 (2016).

33. Surendran S, Girijamma A, Nai R et al. Forkhead box C2 promoter variant c.-512C $>$ T Is associated with increases susceptibility to chronic venous diseases. PLoS ONE 9(3), e90682 (2014).

34. Ferrara N. Molecular and biological properties of vascular endothelial growth factor. J. Mol. Med. 77(7), 527-543 (1999). 
35. Ng YS, Krilleke D, Shima DT. VEGF function in vascular pathogenesis. Exp. Cell. Res. 312(5), 527-537 (2006).

36. Servos S, Zachary I, Martin JF. VEGF modulates NO production: the basis of a cytoprotective effect? Cardiovas. Res. 41, 509-510 (1999).

37. Bouloumié A, Schini-Kerth VB, Busse R. Vascular endothelial growth factor up-regulates nitric oxide synthase expression in endothelial cells. Cardiovasc. Res. 41(3), 773-780 (1999).

38. Perticone F, Perticone M, Maio R et al. Serum alkaline phosphatase negatively affects endothelium-dependent vasodilation in naïve hypertensive patients. Hypertension 66(4), 874-880 (2015).

39. Kim I, Moon SO, Kim SH, Koh YS, Koh GY. Vascular endothelial growth factor expression of intercellular adhesion molecule 1 (ICAM-1), vascular cell adhesion molecule 1 (VCAM-1) and E-selectin through nuclear fctor-kappa B activation in endothelial cells. . J. Biol. Chem. 276(10), 7614-7620 (2001).

40. Kowalewski R, Malkowski A, Sobolewski K, Gacko M. Vascular endothelial growth factor and its receptors in varicose vein walls. Acta Angiol. 17(2), 141-149 (2011).

41. Xu HM1, Zhao Y, Zhang XM, Zhu T, Fu WG. Polymorphisms in MMP-9 and TIMP-2 in Chinese patients with varicose veins. J. Surg. Res. 168(1), e143-e148 (2011).

42. Woodside KJ, Hu M, Burke A, Murakami M et al. Morphologic characteristics of varicose veins: possible role of metalloproteinases. J. Vasc. Surg. 38(1), 162-169 (2003).

43. Raffetto JD, Ross RL, Khalil RA. Matrix metalloproteinase 2-induced venous dilation via hyperpolarisation and activation of K+ channels: relevance to varicose vein formation. J. Vasc. Surg. 45(2), 373-380 (2007).

44. Raffetto JD, Qiao X, Koledova VV, Khalil RA. Prolonged increases in varicose vein wall tension increase matrix metalloproteinases and decrease constriction in rat vena cava: Potential implications in varicose veins. J. Vasc. Surg. 48(2), 447-456 (2008).

45. Pfisterer L, Konig G, Hecker M, Korff T. Pathogenesis of varicose veins - lessons from biomechanics. Vasa 43(2), 88-99 (2014).

46. Murphy G. The regulation of connective tissue metalloproteinases by natural inhibitors. Agents Action Suppl. 35, 69-76 (1991).

47. Serra R, Gallelli L, Butrico L et al. From varices to venous ulceration: the story of chronic venous disease described by metalloproteinases. Int. Wound J. 14(1), 233-240 (2017).

48. Kunt AT, Isbir S, Gormus U et al. Polymorphisms of MMP9 and TIMP2 in patients with varicose veins. In Vivo 29(4), 461-465 (2015).

49. Brissot P, Ropert M, Le Lan C, Loréal O. Non-transferrin bound iron: a key role in iron overload and iron toxicity. Biochim. Biophys. Acta 1820(3), 403-410 (2012).

50. Schulz R, Murzabekova G, Egemnazarov B et al. Arterial hypertension in a murine model of sleep apnea: role of NADPH oxidase 2. J. Hypertens. 32(2), 300-305 (2014).

51. Hirata $\mathrm{Y}$, Yamamoto E, Tokitsu $\mathrm{T}$ et al. Reactive oxygen metabolites are closely associated with the diagnosis and prognosis of cronary artery disease. J. Am. Heart Assoc. 4(2), e001451 (2015).

52. Prasad k, Dhar I. Oxidative stress as a mechanism of added sugar-induced cardiovascular disease. Int. J. Angiol. 23(4), 217-226 (2014).

53. Budyn M, Iskra M, Krasinski $Z$ et al. Serum iron concentration and plasma oxidant-antioxidant balance in patients with chronic venous insufficiency. Med. Sci. Monit. 17(12), CR719-CR727 (2011).

54. Ackerman Z, Seidenbaum M, Loewenthal E, Rubinow A. overload of iron in the skin of patients with varicose ulcers. Possible contributing role of iron accumulation in progression of the disease. Arch. Dermatol. 124(9), 1376-1378 (1998).

55. Zamboni P, Scapoli G, Lanzara V et al. Serum iron and matrix metalloproteinase-9 variations in limbs affected by chronic venous disease and venous leg ulcers. Dermatol. Surg. 31(6), 644-649 (2005).

56. Kartikasari AE, Georgiou NA, Visseren FLJ, Shevela AI. HFE p.C282Y gene variant is associated with varicose veins in Russian population. Clin. Exp. Med. 16, 463-470 (2016).

57. Van DP, Gabreels F, Stevens EM et al. 1998. A second common mutation in the methylenetetrahydrofolate reductase gene: an additional risk factor for neural-tube defects? Am. J. Hum. Genet. 62(5), 1044-1051, (1998).

58. Castro R, Rivera I, Ravasco P et al. 2004. 5, 10-methylenetetrahydrofolate reductase (MTHFR) 677C $>$ T and $1298 \mathrm{~A}>\mathrm{C}$ mutations are associated with DNA hypomethylation. J. Med. Genet. 41(6), 454-458 (2004).

59. Wilmanns C, Cooper A, Wockner L et al. Morphology and progression in primary varicose vein disorder due to $677 \mathrm{C}>\mathrm{T}$ and 1298A > C Variants of MTHFR. EBioMedicine 2(2), 158-164 (2015).

60. Bell RK, Durand EY, McLean CY et al. A large scale genome wide association study of varicose veins in the 23andMe cohort. Presented at: 64th Annual Meeting of The American Society of Human Genetics. San Diego, CA, USA, 18-22 October 2014 (Paper no. 2082M).

61. Cornu-Therard A, Dab W, de Vicenzi I, Valty J. Relationship between Blood Groups (ABO) and varicose veins of the lower limbs. A Case-Control Study. Phleblogy 4, 37-40 (1989).

62. Ellinghaus E, Ellinghaus D, Krusche P et al. Genome-wide association analysis for chronic venous disease identifies EFEMP1 and KCNH8 as susceptibility loci. Sci. Rep. 7, 45652 (2017). 
63. Shadrina A, Tsepilov Y, Sokolova E et al. Genome wide association study in ethnic Russians suggests an association of MCH class III genomic region with risk of primary vericose veins. Gene 659, 93-99 (2018).

64. Serra R, Amato B, Butrico L et al. Study on the efficacy of surgery of the superficial venous system and of compression therapy at early stages of chronic venous disease for the prevention of chronic venous ulceration. Int. Wound J. 13(6), 1385-1388 (2016).

65. Bharath V, Kahn SR, Lazo-Langner A. Genetic polymorphisms of vein wall remodeling in chronic venous disease: a narrative and systematic review. Blood 124(8), 1242-1250 (2014).

66. Serra R, Ielapi N, Barbetta A et al. Biomarkers for precision medicine in phlebology and wound care: a systematic review. Acta Phlebol. 18(2), 52-56 (2017).

67. Serra R, Ielapi N, Barbetta A, Andreucci M, de Franciscis S. Novel biomarkers for cardiovascular risk. Biomark. Med. 12(9), 1015-1024 (2018). 